\title{
Administrative Reforms in Post-Mao China
}

\section{Gordon White}

The Chinese leadership, after spending the last 10 years on economic reform, is now turning to the reform of the state itself; the latter is seen as an essential response and complement to the former. Administrative reform should therefore be seen as one element in a broader process involving not just reform of the state apparatus, but of the economic and political systems as well [for reviews of administrative reform, see Lee 1983 and Burns 1983]. In this article I will focus on the way in which this initiative is affecting the administration narrowly defined - the governmental apparatus - and not the far more numerous group of state employees in the army, educational system, state enterprises or party [for a Chinese analysis of bureaucratic reform, see You 1986].

During the past decade it has become clear that the desired 'modernisation' of the economy requires corresponding changes in all aspects of Chinese society. Reformers regard the existing administration as no longer able to cope with the demands being placed upon it, while the fusion of political, administrative and economic power which it embodies is seen as an obstacle both to economic efficiency and political democratisation. In this article I shall look first at the general context in which administrative reform is taking place, then at the actual changes in administrative practices being envisaged and finally at the nature of the social processes and political forces which are likely to influence the success or failure of administrative reform.

\section{The Economic and Political Context}

Economic reform in China involves two complementary processes - an attempt to reduce the direct role of the state by devolving managerial power from state agencies to basic level enterprises, and a shift in the notion of planning from central direction involving imperative orders to enterprises, to an indirect form of intervention operating through macro-economic policy of the kind we are familiar with in the West. Both tendencies involve a reduction in the direct managerial role of the state, and the substitution of horizontal market-type links for vertical controls. Here 'the state will regulate the market and the market regulate the enterprise', and the relationship between administrators and enterprises will have to change accordingly. On the one hand they will no longer be able to operate by simply giving orders, on the other they will have to take on complex new tasks which will arise from the need to regulate a dynamic market economy.

Turning to the links between administrative and political reform, we have to consider two issues - the immediate political context in which reforms are taking place, and the longer term ideological objectives they are intended to achieve. On the one hand the reform, involving the removal of many existing officials, is undoubtedly an attempt to smooth the transition away from the Maoist era when most of them were recruited (very often on political criteria that would not be acceptable nowadays). So what is presented as a process of administrative rationalisation is in fact a disguised purge to remove those elements obstructing reform, whether they be traditional bureaucrats of the Stalinist kind or products of the Cultural Revolution who are keeping their heads down for the time being. This purging is complemented by the recruitment of a new type of official - younger, more professional, better trained, technically skilled, more favourable to current reforms.

Both these processes serve to weaken the bureaucracy's ability to oppose thoroughgoing economic reform. Market reform in most state socialist countries is likely to be opposed by the bureaucracy because it has the most to lose. Thus in many such countries the reform process is driven forward by an implicit alliance between the political leadership at the top, and various groups at the bottom (workers, managers, peasants and so on) mobilised against a resistant mass of bureaucrats in the middle. The current purge is thus an attempt to decompose that mass and restructure it.

But administrative reform is also part of a more general process of political reform which is seen both as a necessary complement to economic reform and as a desirable goal in its own terms [for the latter argument, see Yan 1987]. The underlying rationale here is what is referred to as 'socialist democratisation', which in the short and medium term can be seen as an attempt to restore to China's political system that legitimacy and effectiveness which was lost during the Cultural Revolution, and to rebuild the political base of the party. This programme of political reform requires changes not only to state institutions themselves, but also in the relationship between state

IDS Bulletin, vol 19 no 4, Institute of Development Studies, Sussex 
and society. I will go into those later, because they are very important in considering the feasibility of any kind of significant administrative reform. But we should also note that if administrative reform implies a Weberian bureaucracy accountable to external forces, then political democratisation outside is essential, since without outside pressures hopes of fundamental changes within the state are small.

\section{The Administrative Reform Programme}

\section{The Problems}

What is thought to be wrong with the Chinese bureaucracy? It is, after all, the oldest in the world, yet it is thought by most Chinese, both ordinary citizens and social scientists, to be an unacceptable entity. Four major problems are generally identified excessive privilege, clientelism, incompetence and political penetration.

First, the bureaucracy is not just a set of administrative institutions, but also a social and political elite. In a bureaucratised system such as the traditional Stalinist-Leninist system, the officials in both the party and the government administration (and in the Chinese case they are fused) have the predominant power to allocate scarce resources, and, as Trotsky once pointed out, if you give someone the power to allocate they don't forget themselves. They can and do use their public powers to build and consolidate their own privilege, a common feature of most state socialist societies, despite attempts to control it.

Second, the bureaucracy operates to a considerable extent through neo-traditional, clientelist, particularistic relationships. To get anywhere without going through numerous offices and getting numerous 'chops' you must know somebody who knows somebody who knows somebody. A complex system of informal connections (guanxi) and connection networks (guanxiwang) exists and determines how the bureaucracy operates within institutions, between institutions, and in relation to its clientele. From the centre to the local levels of government and right down to the enterprises, officials have their own networks and clientele and allocate scarce resources on that basis. Hence most analysts note how traditional the Chinese bureaucracy actually is. Thus Mao Zedong commented himself on the lack of formal organisation, the employment of 'personal friends', the maintenance of 'feudal relationships', the formation of 'cliques', the tendency to 'protect each other' [for an analysis of state 'feudalism', see Su 1986]. These phenomena echo official practices in Imperial China where, according to the saying, when the bureaucrat gets into office his chickens and dogs all prosper. China's state reformers now argue that the Stalinist-Leninist system reinforced this neo-traditional behaviour by reproducing the kind of bureaucratic domination characteristic of the imperial system.

Third, Chinese bureaucracy is a mess. This is not a Weberian bureaucracy - a system of discrete organisation with specific res ponsibilities, coordinated by a concrete and precise division of labour, etc. This is a spawling bureaucracy with overlapping responsibilities, in which coordination can often only be achieved between agencies by the intervention of the party. Clearly some form of institutional rationalisation is essential.

Fourth, reformers are concerned about the political nature of the bureaucracy. At present, political, administrative and economic power is fused so that there is very little formally guaranteed institutional autonomy and no checks and balances between sectors.

In sum, the aim of the reforms is a more efficient, a more flexible and a more circumscribed bureaucracy - an organisational system which is not itself the source of totalistic power but a mechanism which can be used. They understand the problem in Weberian terms - for example, the new Chinese political scientists admit the scientific value of Weber and draw on Western political theorists in his tradition, notably the modernisation theory of political scientists such as Lucian Pye, Samuel Huntington, Myron Weiner and David Apter. They see the Weberian model of a 'rational-legal' bureaucracy as highly desirable at China's current developmental stage. The solutions which they are advocating are consistent with this external model.

\section{The Solutions}

\section{(i) Structural Reforms in the State System}

First there is a desire to depoliticise the state administration. The bureaucracy has been a political entity, in terms of behaviour, recruitment and organisational composition. It is penetrated at all points by the party, which has groups in every major bureaucratic institution and a large percentage of bureaucrats are also party members. There is a great deal of overlapping of party and state offices, of 'wearing two hats'. What the reformers want is something more neutral, more professional, and something that can be used as an instrument by politicians who are themselves an exogenous force.

Second, China's reformers want a 'scientific' organisation. There is a current fascination with science in general, and with scientific methods of administration in particular. Western management and administrative theories are taken very seriously because it is felt they have a scientific core which can be applied elsewhere to produce a scientific organisation capable of generating scientific decisions: This is a response to a situation where, it is thought, major and minor 
administrative decisions have been more or less arbitrary, dependent on particularistic ties or political whims. For example, many major investment decisions have been made in theory according to some kind of planning rationality, but often in practice in response to the particular needs of local party bosses, resulting in large-scale misallocation of scarce resources.

Third, there is a move towards formalisation - a move away from informal methods of administrative action based on 'connections' or enforced 'muddling through'.

Fourth, there is a desire for decentralisation and pluralism. The reformers want an administration which plays a much less direct and pervasive role in society, is institutionally more circumscribed and has much less power. They want a much more differentiated, diffused, and deconcentrated system of internal power relations within the state and a move from monism to pluralism externally [for this idea, see the speech by Su Shaozhi reported in Ta Kung Pao, Hong Kong, 17 September 1986]. Throughout the whole society - in the economy, in the political and administrative systems - there is the desire to break things up into separate spheres, each with its precise responsibilities, each with its own degree of autonomy, and each serving as a check and a balance in relation to the others. Thus Western theory of the separation of powers, formally excoriated as 'bourgeois', is now gaining respectability, and political scientists who support it can now do so publicly (though still with caution).

In effect, China's state reformers are attempting to create something very close to a Western civil service based upon Weberian principles, with the government bureaucracy perceived as a rational instrument under the control of external political forces. After nearly 40 years of experiencing the bureaucracy as a master, the Maoist idea of officials 'serving the people' notwithstanding, the idea of it as a servant is very beguiling.

This concept of reformed administration is to be achieved by certain basic processes of organisational restructuring. We can understand these in terms of two vertical and two horizontal processes. Vertically, there is to be decentralisation - transferring power from central to local governments, and from government in general to increasingly autonomous enterprises. Horizontally it means differentiating more clearly between specific bureaucratic institutions and also separating the Communist Party from the government bureaucracy. Let us look at these processes in more detail.

First, decentralisation within the government machine means giving local governments more managerial and regulatory powers and bringing about a clearer division of labour between them and central government [on these issues, see White and Benewick 1986]. In the past this relationship has involved a complex, messy and unpredictable hierarchical game for power and resources. Reformers now want to rationalise this, for example, by bringing in a tax system based on clear principles of revenue sharing. These issues are very familiar to students of Western local government, but they have not been addressed in China until very recently.

Second, decentralisation means making state enterprises more autonomous bodies; in the post-reform economy they may still be called state enterprises, but they will not operate under the direct control of a state agency as before. This process also involves reducing the power of the party within the enterprise - very often the party secretary has been the dominant figure, not the manager. This change also raises the broader question of ownership - of how to allow a stateowned enterprise to operate as though it were not a part of the state. It requires an ownership system which involves an element of responsibility and supervision, but at the same time allows the enterprise to behave in a flexible and autonomous way. From the reformers' perspective, if the bourgeoisie can do this, why can't the socialist state do it?

Horizontally, the reform first envisage an effort to clarify and differentiate in a much more defensible way between specific bureaucratic institutions at the same level, so as to tackle longstanding problems of overlapping, duplication, competition, and bureaucratic accretion. Second, it is intended to achieve a much clearer separation between the party and the government bureaucracy. In the past the party has been contained within the bureaucracy, in effect a structural part of it. In practice this means that power is concentrated in a small committee where the last say often rests with one individual who may be both head of the government and party organisations at his/her level.

This overconcentration of power is seen as harmful, and the reforms aim to separate the party and government into their specific areas of competence. Thus, for example, at the basic level in the countryside, the administrative village (xiang), this means taking the party apparatus out of the economic administration of the local economy. At the national level, party groups were organised in each major government office; they are now to be removed. As the party recedes, so political controls over the bureaucracy will be more external, more parametric. Of course there will still be party members within the bureaucracy, but ideally the party will be 'outside', making political decisions which will then be transmitted to a bureaucracy which has its own protected professional sphere. All of this, it should be noted, however, is still very recent - the issue was raised at the 13 th 
Communist Party Congress in October 1987, but so far little progress appears to have been made.

This is part of a broader issue of separation of powers. How does one separate the party, the government, the judiciary, the people's representative congresses, and give each its own authority and make them check and balance each other? From the reformers' viewpoint, in the last analysis the autonomy of each element in this system can only be guaranteed through the establishment of effective legal checks upon the exercise of power, and a correspondingly independent judiciary. This means the separation of the party from the judiciary as well as from the governmental administration. Most of the reformers accept that the state system in the past has been based on 'power', whether institutional or personal, and to that extent has always been arbitrary. This they contrast with the notion of a universal rule (contractual law for example), applied in an impartial way on the basis of equality between the parties.

Thus the reforms aim to transfer state decision, rules and regulations from the area of the political or the personal into the realm of the legal, in particular using the legal system as a check on arbitrary power. This, in turn, requires two developments - a system of administrative law comparable to that in Western countries, (notably in France), which may be administered by special courts; and, more generally, a system of autonomously operated judicial rules which protect the rights of enterprises, individuals etc., both against each other and against the state.

This is a fundamental change - in the past the individual could only protect himself against a powerful official by having equally powerful allies in the party or administration. Thus judicial reform is central not only to administrative but also to political reform. But the question which has still to be confronted is how the autonomy of legal institutions can be guaranteed, since at present they are still largely creatures of the party.

\section{(ii) Reorganisation within the Administration}

The reforms also envisage changes within the apparatus itself in order to make it more efficient, impersonal and accountable. At present bureaucracies are over-staffed, employment is guaranteed for life, systems of recruitment and promotion do not exist, and, in many cases, officials have very little of substance to do.

With these goals in mind, the reforms aim to introduce a system of rules, regulations, procedures, performance criteria and so on, intended to raise the quality and effectiveness of staff. Revised personnel policies will, it is hoped, raise organisational efficiency by reducing over-staffing, and eliminating the use of political or personal criteria in bureaucratic recruitment. Ultimately, the aim is to create a professional bureaucratic consciousness beginning with the establishment of administrative training schools. It is hoped that the new breed of officials will develop a professional 'public service' identity and act accordingly.

Thus the Chinese are trying to institute general procedures which would be taken for granted in Western bureaucracies: systems of recruitment, supervision, evaluation, promotion, in-service training, terms of service and so on. At present, reformers are ambivalent on the central issue of bureaucratic terms of service. They are guided by two sets of principles here - by the Weberian principle of a professional career involving security of tenure, and the neo-liberal notion of short-term contracts tied to precise performance criteria with the ultimate sanction of dismissal. While the latter may be appealing from a narrow efficiency viewpoint, it will prove politically difficult to implement, and may damage the broader goal of establishing a 'civil service' worthy of the name (job security being an important source of protection for administrators against political manipulation).

\section{(iii) Redefining the Party and Political System}

In a bureaucratic system dominated by the party, depoliticisation requires a fundamental transformation of the latter's role and formal organisation. In the post-reform era, it will not have so much to do - for example, it will no longer actually be running production in a textile factory. Yet, the reformers recognise that its new role requires a capacity to supervise the bureaucracy effectively, and that this will require its membership to become more representative, its internal processes more democratic. At the very least, this will involve scope not for internal discussion but debate; more optimatically, it could allow scope for organised fractions, and even the possibility of a kind of multi-party system within the party.

If the party's role can be redefined, many theorists feel that the party will in fact be strengthened. In the past, it is argued, the party had over-extended itself, reaching not only into bureaucracy but into every social and economic institution. Perhaps there is an organisational law here - the more a single institution incorporates other institutions within itself the weaker it becomes. All the tensions and failures of Chinese development, all the accompanying conflicts of interest have been expressed within it, and its solidarity and autonomy have been compromised.

Secondly, China's political reformers argue that, if the party and bureaucracy are to be made accountable to external forces, there has to be an effective electoral system which provides legislative representatives with adequate resources. All state socialist societies have an electoral system - a system of representative congresses, universal suffrage, where people go to meetings and are theoretically supposed to supervise 
the activities of the government. But if one attaches political weights to party, bureaucracy and the representative system, the first two heavily outweigh the third. The legislative system of 'people's representative congresses' has had virtually no power in China until the last few years, when some limited steps have been taken to improve their powers. In the past, people's representative congresses at the local level had virtually no resources at their disposal - no offices, no committees, no standing bodies etc. The authorities are now beginning to institutionalise these bodies by providing them with some kind of standing body which operates throughout the year. Whereas in the past each congress met only once or twice a year and basically listened to what the government had to propose; now they have a secretariat which has the power to scrutinise the bureaucracy and say, for example, 'You want to spend $x$ on this? Right, let's have a look at it before we approve your proposal'. Then when the issue comes up for general debate and decision in the full congress, the representatives can raise questions because they now have the limited institutionalised capacity to generate the expertise to do so. Thus there have been some improvements, but the disparity in power between the three branches of government is still enormous.

\section{The Dynamics of Change}

The previous section demonstrates that Chinese reformers have a sophisticated conception of what needs to be done to 'modernise' their political and administrative systems. But it is equally clear that the attempt to achieve their aims will be very difficult, not the least because the party and the government bureaucracy, which have a great deal to lose in the process, are the very agencies charged with implementing it. At the moment it seems that no-one in the Chinese leadership is able to take on this highly complicated and entrenched system of power. In the case of administrative reform, one can cite many cases where attempts to streamline and rationalise the bureaucracy have worsened rather than improved the situation. Over the last 10 years of reform the bureaucracy and its costs have increased at a rate faster than other sectors such as industry. It is also true that market reform, which is based on the desire to reduce the role of the state, actually produces a state with a far wider range of responsibilities, so one can hardly expect it to 'wither away' [for a discussion of these new functions see Xu 1986]. To understand the prospects for successful reform of the state, we must look at the extent to which the changes in society, polity and economy are cumulative and interactive. To what extent can those broader processes be expected to produce irreversible shifts in the distribution of power in Chinese society which will provide a political context favourable to the kind of

\section{administrative changes now on the agenda?}

Chinese political scientists see progress in the state reforms in terms of interaction between three key processes - political modernisation, marketisation and institutionalisation. They assume that each will condition the other, and that none will be able to run too far ahead. Obviously market-oriented economic reform is now in the lead because it is less politically sensitive and it brings immediate rewards, but it can be seen as laying the foundations for political and institutional change. Let us discuss each process in turn.

First, political modernisation, like economic reform, is a direct response to an increasingly complex and sophisticated society. As incomes and education have improved, people have more time, take a greater interest in politics, and have greater confidence in their ability to press demands. This means a shift from a subject to a participant political culture, which creates pressures to which the political authorities must respond or face increasing tension. Certain groups are crucial here; the intelligentsia and, increasingly, a new stratum of entrepreneurs - industrial and commercial managers provide an important impetus for political reform.

Second, there is the evolution of an increasingly marked-based economy (the Chinese refer to this process as 'marketisation'). The prominent political scientist, Su Shaozhi, from the Institute of Marxism Leninism Mao Zedong Thought in Beijing, in a recent article referred to the market as a much more potent remedy for the problem of bureaucracy than any degree of political manipulation or administrative interference [China Daily, 20 January 1988]. Here he is making a general statement, but he is also referring to past events and particularly to the Cultural Revolution, which attempted to curb the bureaucracy by political means, such as mass criticism and sending down of officials to the grass-roots or to special schools. After all the Sturm und Drang of the Cultural Revolution, however, the bureaucracy was even worse than before, because it had developed more effective measures to protect itself and ensure that this would never happen again.

Thus, for $\mathrm{Su}$ and other political reformers, the magic underminer of the bureaucracy is not political pressure but the market. There is an implicit political discourse within the currently very neutral talk about markets as an impersonal allocative mechanism. The market is seen as a powerful political force. Economic decentralisation and the redefinition of state ownership will shift real control over, and responsibility for, assets to the enterprise or some intermediate body, thus reinforcing the deconcentration of power in society, with inevitable political consequences. Another Chinese political scientist, Yang Baikui, puts it like this [Yang 1987]: 'Economic independence for 
enterprises will provide conditions for political democracy and place high demands on political democracy. Enterprises will thus have greater political independence and will be able to express independently their political desires, and supervise the activities of the government more effectively'. This kind of analysis suggests that economic reform provides the 'material basis' for political reform. As enterprises with relatively autonomous economic power emerge, then they will be in a position to direct real pressure towards the political authorities and administration to secure a regulatory environment to their advantage.

Third, Chinese analysts emphasise the importance of 'institutionalisation'. I would see this as the process whereby organisations or patterns of activity acquire stability, authority and autonomy. It is a process whereby existing organisations are changed to take on these characteristics, or new ones arise that have them. These institutions increasingly will be expected to represent the interests and demands of society and economy and have an institutional interest and a legally defined capacity to control the government bureaucracy and, a fortiori, the party.

This latter phenomenon relates to what is perhaps the most central and far-reaching transformation implicit in the reform process. It appears likely that the impetus to the reform of state and politics is not going to come from the party itself, which wants only the minimal reforms needed to secure a well-functioning economy. If there is to be fundamental change, then this will have to be induced by pressure from society itself and more particularly from autonomous institutions within it - in other words, from the development of a social form of 'civil society'.

In established socialist systems there is virtually no 'civil society' in the sense of autonomous social organisations. All social institutions are controlled to a greater or lesser degree by the central political authority, and a wide array of relatively autonomous or autonomous institutions organised according to some kind of principle of association does not exist. If the current economic reforms are to provide the context for civil society to emerge, new institutions have to be created, and existing institutions will have to change, and take on new functions, and in particular to start acting autonomously $v i s-\grave{a}$-vis the state. Indeed, this is beginning to happen in both Europe and China - trade unions are beginning to act on behalf of their members, basic level mass organisations like student organisations are beginning to articulate the interests of their constituents. In China, for example, the Women's Federation has begun to argue for the interests of women, which in the past have tended to be submerged within a general conception of socialism which downplays gender differences. Yang Baikui describes this general process as follows:
With the development of the economic reforms in various aspects, social groups which are independent to a certain extent will be formed in our country, such as workers groups in factories and mines, groups of entrepreneurs, the group of private business people and industrialists, the group of agricultural labourers, and so on. Some of them are shareholders and some are not. They are relatively independent . . . [it is] the relative independence and development of these intermediate strata' [which] will bring changes to the socialist political structure.

Thus, to the extent that society creates the basis for autonomous organisation both in the market sphere and in the general sphere of social and political organisation, it will be less easy for a central state to retain its monopolistic power and resist pressures from below for socialist democratisation and administration reform. The new structures will generate power and use it, because they have an interest in controlling and rationalising the activities of the state. Thus the possibility of administrative reform will not be a response to a sudden transformation, but a gradual and interactive process in which large numbers of relatively small forces all nibble away at the mass of power at present monopolied by the party and the bureaucracy. Each must rely on the other, and none can make real advances without the others in attendance. The major changes which have already taken place in China show that this process is already well under way. It is too early at present, however, to say how far they will be taken, and what kind of society and polity they will eventually produce.

\section{References}

Burns, J. P., 1983, 'Reforming China's bureaucracy, 1979-82', Asian Survey XXIII:6 (June)

Lee, Hong-yung, 1983, 'Deng Xiaoping's reform of the Chinese bureaucracy', in R. A. Morse (ed.), The Limits of Reform in China, Westview Press, Boulder (Co.)

Su Shaozhi, 1986, 'Reform of the political system and opposition to the influence of feudalism' Renmin Ribao (People's Daily), 15 August in BBC, Summary of World Broadcasts: Far East No 8345

White, Gordon and Benewick, Robert, 1986, 'Local Government and Basic-Level Democracy in China: Towards Reform?', China Research Report No 3, IDS, Sussex

Xu Zhaoming, 1986, 'Summary of a theoretical forum on the functions of government', Guangming Ribao (Glorious Daily), Beijing, 28 July

Yan Jiaqui, 1987, speech reported in Ta Kang Pao, Hong Hong, 13 November, in BBC, Summary of World Broadcasts: Far East, No 0005 
Yang Baikui, 1987, 'Some questions on China's political reform', Guangzhou Yanjiu (Canton Research), No 2, pp 30-33
You Chunmei, 1986, 'Current administrative reform in China', International Review of Administrative Sciences, vol 52 no 2 (June), pp 123-44 